\title{
EngagedScholarship@CSU
}

$12-1-2008$

\section{The Transatlantic Pocahontas}

Gary Dyer

Cleveland State University, g.dyer@csuohio.edu

Follow this and additional works at: https://engagedscholarship.csuohio.edu/cleng_facpub

Part of the Literature in English, North America Commons

How does access to this work benefit you? Let us know!

\section{Publisher's Statement}

Article originally published as Dyer, Gary, "The Transatlantic Pocahontas," Nineteenth-Century

Contexts, Vol. 30, No. 4 (2008): 301-302. (C) 2008 Taylor \& Francis. Doi: 10.1080/

08905490802550352

\section{Recommended Citation}

Dyer, Gary, "The Transatlantic Pocahontas" (2008). English Faculty Publications. 21.

https://engagedscholarship.csuohio.edu/cleng_facpub/21

This Article is brought to you for free and open access by the English Department at EngagedScholarship@CSU. It has been accepted for inclusion in English Faculty Publications by an authorized administrator of EngagedScholarship@CSU. For more information, please contact library.es@csuohio.edu. 


\title{
The Transatlantic Pocahontas
}

\author{
Gary Dyer \\ Department of English, Cleveland State University
}

[Pocahontas] continued her kindness to the new settlers, and in 1612, married a Mr. Rolfe. By this gentleman she was instructed in the principles of the Christian religion, and baptized, by the name of Rebecca.

—William Gifford, 1816 (Jonson 5: 228 n7)

In good hands Pocahontas would make a capital story but it must be written by some one who knows American \& Indian manners more familiarly than can be acquired from books.

[...] she had that lurking demon

Of double nature, and thus doubly namedFirmness yclept in heroes, kings, and seamen,

That is, when they succeed; but greatly blamed As obstinacy, both in men and women,

Whene'er their triumph pales, or star is tamed:And 'twill perplex the casuists in morality

To fix the due bounds of this dangerous quality.

—Lord Byron, Don Juan (1819-24), XIV.89.1-8

In 1822 Walter Scott commented in a letter to his publisher that even though "Pocahontas would make a capital story," the story would require a writer who, unlike him, knew "American \& Indian manners" firsthand. Yet, I will propose, Scott by 1822 had already made a capital story of Pocahontas, even if he was unaware that he had done so. This essay examines his adaptation of the Pocahontas legend to twelfthcentury England in Ivanhoe (1819) and the American Catharine Maria Sedgwick's rewriting of Scott's adaptation in Hope Leslie (1827), her romance of seventeenthcentury Puritan Massachusetts. Ivanhoe not only transfers elements of the Pocahontas myth to the Middle Ages (thereby circumventing Scott's unfamiliarity with New World manners) but also concentrates on critiquing the ideology that the myth embodied, an ideology that romanticized conversion and seduction: whereas the name "Rebecca" marked Pocahontas's assimilation, Scott bestows it on a woman who bravely resists 
assimilation. Besides making this historical claim about Pocahontas's contribution to nineteenth-century resolute womanhood, I utilize the history of the Pocahontas narrative to make a methodological point about transatlantic cultural studies.

Studies relating British and United States literature in the Romantic period, few though they are, mostly limit themselves to influence that flows westward, and critics have sometimes been conspicuously averse to exploring other possibilities. ${ }^{1}$ We should, however, be alert to all possible directions in which influence can move. As James Chandler observes, "though the case of America helped shape a concept of culture in which Britons could reimagine their own culture in its historicity, there is surprisingly little on the question of how American culture registered in the literature of the British Romantic period" (447). ${ }^{2}$ Although specialists in British Romanticism have appreciated the role "the New World" played in the lives and works of Romantic authors, they have tended to neglect the role of texts written by people who lived in the United States, whether before or after independence. Obviously the two sides of the relation between the countries were not equal: for example, whereas most novels published in the former colonies came from Britain, only eight novels originating in the United States were republished in Britain before $1821{ }^{3}$ Yet certain American texts and American stories were pivotal at certain moments, one of which is the focus of this essay.

Romanticists exploring transatlantic intertextuality should bear in mind how it has been examined and theorized by scholars of adjacent historical periods. In The Imaginary Puritan (1992), which focuses on the era that extends from Milton to Samuel Richardson, Nancy Armstrong and Leonard Tennenhouse complain, rightly, that "any number of scholars have shown how English culture changed in the colonial setting," but "few if any have bothered to consider what happened when colonial writing flowed back across the Atlantic to England" (197). Armstrong and Tennenhouse propose to "think of England as part of a larger nation whose boundaries extended overseas to North America" (196). The most prominent recent argument for eastward-flowing influence is Armstrong and Tennenhouse's claim that the English novel, for them represented by Richardson's Pamela (1740-41), owes some of its defining traits to the American women's Indian captivity narratives of the late seventeenth and eighteenth centuries, exemplified by Mary Rowlandson's account (1682). Armstrong and Tennenhouse turn to the women's captivity narratives after looking in vain for British texts predating Pamela in which Englishness is "embodied in a nonaristocratic female" and "the female in question [is] a virtually inexhaustible source of English prose" (202; see also Armstrong, "Captivity" 373).

I wish to make the case for another instance of eastward transatlantic influence, and in the case of the Pocahontas story the Atlantic currents arguably flow in both directions, as they do not in Armstrong and Tennenhouse's account. At first glance, Hope Leslie might appear to be just one more example of Scott's impact on nineteenthcentury fiction, but Sedgwick, I suggest, actually returns Ivanhoe's story to one of its likely sources, the conflict of English settlers with Native Americans. Given how the historical romance, like its predecessor the national tale, often depicted national difference by way of gender difference, particularly by using intercultural marriage as a 
metaphor or synecdoche for unions between nations, an observer might predict that some early-nineteenth-century British author would take advantage of possibilities offered by the Pocahontas story. ${ }^{4}$ Scott's novels prior to Ivanhoe deal continually with the union of England and Scotland, which is sometimes figured as marriage (when Edward Waverley weds Rose Bradwardine, for example). The Pocahontas story offered the opportunity for a more critical take on such figurations, and when Scott drew on British and American accounts of Pocahontas, he produced, in Ivanhoe, one of the nineteenth century's most vivid examinations of how race and gender intersect. Much like Armstrong and Tennenhouse, I argue that transatlantic influences were crucial to the representations of womanhood so conspicuous in the canonical English-language novel. The Pocahontas motif in Ivanhoe and Hope Leslie not only illuminates the emergence of a recognizable (because so modern) male subject fighting with himself over his passions, but also helps us chart the rise of the domestic woman as her fortitude grows stronger. Yet, as I will show, the fact that women's fortitude was celebrated as passive fortitude, the kind of fortitude at which Indians excelled, suggests that this fortitude did not promise to empower women.

Transatlantic cultural relations in the eighteenth and nineteenth centuries have traps for the unwary, and these traps will be examined in the present essay's final section. Transatlantic studies in general is booming, and the "Old" and "New" Worlds have been shown to be interrelated in more complex and interesting ways than we assumed previously. I have in mind such influential books from the 1990s as Paul Gilroy's The Black Atlantic (1993) and Joseph Roach's Cities of the Dead (1996), which is subtitled "Circum-Atlantic Performance." This boom is part of a more general trend within literary and cultural studies. Proclaiming disdain for conventional boundaries has long been a conventional gesture, yet whereas transgressing the boundaries between disciplines used to receive the emphasis, more recently the trend has been toward exposing and documenting unexpected crossings of temporal, geographical, and cultural borders. David Wallace's Chaucerian Polity (1997), which like Roach's book won the Modern Language Association's James Russell Lowell Prize, draws much of its force from refusing to recognize the traditional spatial-temporal line separating "Renaissance" Italy from "Medieval" England. Books and articles on border-crossing frequently assert that specific cultural practices spread in ways that previous scholars did not recognize or think to look for, in part because the scholars assumed that culture would spread in one direction only.

Those of us working in transatlantic studies in the Romantic period ought to be wary of certain errors that often beset studies of cultural boundary-crossing. A significant subgenre of work on border-crossing concerns marginalized groups' influence on more powerful ones: Shelley Fisher Fishkin's Was Huck Black? (1993), for example, argues that Mark Twain's protagonist and narrator speaks with a distinctively African American voice. Fishkin's subject, the relation of American culture in general to African American culture, differs in many ways from the principal subject of this essay, the relation of Britain to the United States, but the shortcomings that have been identified in Fishkin's argument suggest some pitfalls that new work in transatlantic cultural studies ought to swerve to avoid. The Pocahontas story helps us identify these 
pitfalls because of the valuable insights that later writers, like Scott and Sedgwick, extracted from the story: Ivanhoe and Hope Leslie teach a lesson about culture's relation to power, and we should bear this lesson in mind when pursuing comparative work of any kind. The melding of cultures is seldom as complete or as painless as the victors in a conflict might like us to believe.

\section{Scott's Jewish Pocahontas, Sedgwick's Indian Rebecca}

Sedgwick's debts to the Pocahontas legend in Hope Leslie are obvious, and a few critics have noted that her novel echoes Ivanhoe, but no one has inferred from these connections that Scott's novel may be a step in the evolution of the Pocahontas myth. ${ }^{5}$ The Indian princess, I propose, is alluded to in the travails of three female characters in Ivanhoe-Rowena, Ulrica, and, particularly, Rebecca. Hope Leslie returns Scott's Pocahontas story to America, extending and refining his adaptation of the legend (Sedgwick's character Magawisca, the Pequot chief's daughter, is her novel's Pocahontas figure). Different sources that were available to Scott and Sedgwick emphasized different elements of the Pocahontas story, sometimes omitting events, but the basic plot was clear. In December 1607, Pocahontas, the Algonquian sachem Powhatan's favorite daughter, interposed herself between John Smith and his executioners, thereby saving his life. Later she warned the white settlers of Indian attacks. She was kidnapped by Captain Argall in 1613, subsequently converted to Christianity (the first conversion among the Indians of Virginia), and married John Rolfe. The central device of the Pocahontas myth, protection being reciprocated, is also central to Rebecca's and Magawisca's stories. The protection is reciprocated between genders: a woman saves a man's life, and later he risks everything to rescue her. Protection is also reciprocated between ethnic and religious groups: an Indian or Jew saves an English or AngloAmerican Christian, who in turn saves the Indian/Jew. Ivanhoe and Hope Leslie reveal, however, that the equality implied by this symmetry is illusory. Scott and Sedgwick revise the Pocahontas narrative at key points so as to subvert its idealized vision of how gender domination and racial domination function: for example, one reason Rebecca needs to be rescued is, ironically, her earlier decision to save Ivanhoe.

Hope Leslie treats Ivanhoe as a rewriting of the Pocahontas story, and we ought to treat it as such. By the time Scott composed Ivanhoe in 1819, he had enjoyed access to accounts of Pocahontas written by William Gifford, William Robertson, and perhaps Abiel Holmes, and Scott may have known other accounts as well. He certainly knew the Indian princess's story from the History of America (1777-96) written by his former teacher Robertson (see Robertson 8: 35-46). ${ }^{6}$ At Scott's death, his library at Abbotsford included the 1808 London edition of Holmes's American Annals, which included the story of Pocahontas (Catalogue 30; Holmes 1: 158-59, 165-66, 181, 191). ${ }^{7}$ In February 1822, over two years after Ivanhoe was published, Archibald Constable sent Scott two books on the Virginia settlement, Raphe [Ralph] Hamor's A True Discourse of the Present Estate of Virginia (1615) and Robert Beverley's The History and Present State of Virginia by a Native of the Place (1705), and he suggested that a new novel about Pocahontas would sell. Scott agreed, but felt that the job demanded a writer who knew 
American and Native American culture firsthand (he mentioned Washington Irving). ${ }^{8}$ Scott went on to say, "As for Pocohontas [sic] I have some idea of a passage in Ben Jonson describing her as frequenting 'the womb of tavern'" (Scott, Letters 7: 80n, 81). This passage appears in Jonson's The Staple of News (1625), and the only edition of Jonson's plays that was in Scott's library, William Gifford's (see Catalogue 209), glosses the reference to Pocahontas with a two-page footnote that summarizes her story, including her adoption of the name "Rebecca" when she converted (Jonson 5: 227-28 n7). Taken together, Robertson, Holmes, and Gifford recount the entire Pocahontas legend. (Holmes omits the princess's abduction by the colonists, while Gifford unexpectedly leaves out her rescue of Smith.) Robertson never mentions Pocahontas's adopted Christian name, but the evidence suggests that Scott found this information in Gifford, Holmes, or some other source: in Ivanhoe he bestows the name "Rebecca" on a fictional character who resembles Pocahontas in other ways, as I will show. ${ }^{9}$

Details in Ivanhoe, such as Rebecca's name, point to Pocahontas, and the evidence of Scott's exposure to the legend is as strong as might be anticipated: although his sole reference to Pocahontas by name occurs in a letter written well after Ivanhoe's appearance, and we know of only three accounts of her life to which he demonstrably had access, the probability is that no stronger external confirmation of indebtedness would survive-not even if the echoes of the Pocahontas story were deliberate. Admittedly, we cannot entirely rule out alternative origins for these echoes because we cannot reconstruct everything Scott read and heard (and he read and heard a lot). Scholars have identified a range of classical and medieval precursors for the Pocahontas legend, stories in which a man "becomes the captive of the king of another country and another faith, and is rescued by his beautiful daughter, a princess who then gives up her land and her religion for his" (Young 409). Scott knew many of these narratives, such as the myth of Ariadne and Theseus or the medieval romances that exemplify what scholars have termed "the Enamoured Moslem Princess" motif (see Mitchell 133; Mossiker 82-83). Perhaps most arguments for eastward influence will have shortcomings of this kind: the evidence will always be limited, and other, European sources hard to rule out. Armstrong and Tennenhouse's claim about the function of Indian captivity narratives arguably becomes vulnerable when they hang their thesis on their lack of contrary evidence: "Where, if anywhere prior to Pamela, did Englishness come to be embodied in a nonaristocratic female? And where, if anywhere prior to Pamela, was the female in question a virtually inexhaustible source of English prose?" These questions are meant to be rhetorical-Armstrong and Tennenhouse's answer is "Certainly not in England" (202) — but someone who has read more widely than I have may be able to come forward with a list of examples. ${ }^{10}$

But the existence of stories like that of Ariadne and Theseus does not damage my argument. Even though the Pocahontas legend is only a relatively recent variant of a narrative that goes back thousands of years, the legend nevertheless possesses distinctive features, largely absent from other sources, and because these features appear in Ivanhoe, Scott probably was indebted to accounts of Pocahontas. In few of the classical or medieval sources that were noted above is the man's culture more powerful than the woman's, and in almost none of them is the woman's culture destined to be destroyed. 
Such was the case in 1607 Virginia: although John Smith could not foresee then that his colony would prevail and the Indians would be decimated, every eighteenth- or nineteenth-century refashioner of the Pocahontas story and every reader was aware of what ensued. ${ }^{11}$ From the perspective of Scott's era, Pocahontas's predicament as an Algonquian Indian was as dire as that of a Jew in medieval England or a Pequot in seventeenth-century Massachusetts.

In Ivanhoe, Rebecca's situation after being abducted is frequently termed "captivity" $(191,327,335,373,394)$, and because she is Jewish the word obviously connotes the Hebrews' Babylonian imprisonment, yet the word also evokes the stories of people, particularly women, taken captive amid the conflicts between Native Americans and Europeans. The Pocahontas story is a captivity narrative not just because John Smith was a prisoner, but because Pocahontas was a prisoner. Whatever Scott intended, Ivanhoe serves to remind us that Pocahontas was kidnapped by the English colonists before she converted and married a white man. She was as much a captive as the white woman Mary Rowlandson, even though most narratives of Pocahontas's life downplay this fact (Smith would be deemed a "captive," the Indian princess a "convert"). Furthermore, Pocahontas's captivity was more formidable than those in most captivity narratives, since the men who held her were so powerful, and escape so improbable. Rowlandson, after all, succeeded in returning home, whereas Pocahontas died in England, and would never have lived among the Indians again. All accounts of Pocahontas that Scott could have known were shaped by the authors' knowledge that the Indians were doomed, and no nineteenth-century reader could believe that the two sides in the conflict had ever been equal.

After Ivanhoe is wounded at the tournament at Ashby, Rebecca's medical care saves his life. By treating him, she tries "to avert the stroke of death" (234), and Scott's metaphor makes the comparison to Pocahontas's heroism inevitable: as the Marquis de Chastellux records in his Travels in North-America, in the Years 1780, 1781, and 1782 (1787), Smith was about to receive "the stroke of death" when Pocahontas intervened (Chastellux 2: 139). ${ }^{12}$ Later, when Rebecca is about to be condemned for "sorcery, seduction, and other damnable practices" (332), she demands her right to judicial combat. Ivanhoe arrives just in time to fight in her defense, although he wins, sparing her death at the stake, only because his opponent, the Templar Brian de Bois-Guilbert, falls dead from "the violence of his own contending passions" (392). When Sedgwick's Pequot chief Mononotto is about to execute Everell Fletcher, his daughter Magawisca intercedes, so that "the stroke aimed at Everell's neck" severs her arm (93), and seven years later, the Puritans put Magawisca on trial for organizing Indians against the whites. Everell, with Hope Leslie's collaboration, arranges Magawisca's escape.

All the Pocahontas texts Scott might have read romanticize her experiences. In the United States of the eighteenth and early nineteenth centuries, Pocahontas's marriage to Rolfe was usually depicted as an ideal blending of White and Indian (many Virginians claimed descent from the couple). Americans thereby enshrined what Robert Tilton calls a "fantasy of absorption of the established people into the culture of the newcomers" (3). Pocahontas's chroniclers believed that she was rewarded amply for protecting Smith and the other colonists, insofar as she, too, was rescued, not from 
execution but from savagery. From such a viewpoint, her heroism appeared to have been well repaid: she was instructed in the Christian religion, she gave birth to children who represented a new people, and she was immortalized. Not only do accounts of Pocahontas emphasize the strength of her feelings for whites, they transform her feelings into romantic love. Writers played up the love she and Rolfe reportedly felt for each other, and in 1803 John Davis even endowed the Indian princess with a mature woman's passion for John Smith, although she actually was only twelve years old when she defended him. ${ }^{13}$ By stressing Pocahontas's will, Davis implies that she possessed substantial control over her fate.

These stories of Pocahontas nevertheless invite skeptical reading to subvert their pleasant myths. Sources from the Romantic period seldom spell out that Pocahontas was kidnapped-Chastellux is the only instance (2: 142) — yet any smart reader, such as Scott or Sedgwick, could infer that her choices were restricted. No matter how much affection the real Pocahontas felt for some whites, the story of voluntary conversion and voluntary seduction that was passed down hardly typified what occurs when one nation conquers another. Indeed, to speak of free choice in such a situation is misleading. Scott's and Sedgwick's crucial revision of the Pocahontas legend is to demythologize the choice involved in Pocahontas's conversion to Christianity and her union with an Englishman. In the eighteenth and nineteenth centuries, the terms "seduction" and "conversion," which to twenty-first-century ears imply some degree of consent, were applied even to a person who had little opportunity to refuse. If seduction is often assault, so, too, is conversion. Michael Ragussis has shown that Ivanhoe "demystifies the trope of conversion by historicizing it - that is, by redefining it in the context of the history of the Jews" (93). Scott also uses "the parallel stories of Ulrica, Rowena, and Rebecca" to explore "woman's role in the annihilation or preservation of racial and national identity" and he "helps to crystallize the idea of conversion as rape" (102). Ivanhoe and Hope Leslie insist upon the cost that coerced decisions always have for the disempowered parties.

Reading Ivanhoe and Hope Leslie as responses to the Indian princess's story, one quickly perceives that Scott and Sedgwick supply a dose of reality to counteract the mythmaking that dominates almost all versions of the Pocahontas legend. Whereas Pocahontas was immortalized for defending the English, in Ivanhoe and Hope Leslie a woman's ability to provide aid is held against her. Rebecca's instructor in medicine, Miriam, died at the stake for witchcraft, "a sacrifice to the fanaticism of the times" (232, see also 311), and, predictably enough, Rebecca's success curing Ivanhoe and her father Isaac's Christian servant Higg (324-25) is cited by the Templars as evidence of sorcery. In Hope Leslie, Nelema, the old Indian woman who befriends Magawisca, faces a charge of witchcraft after she cures Cradock of a poisonous snakebite (103-09), and this episode may lead the reader to anticipate that Magawisca's rescue of Everell will somehow backfire on her. ${ }^{14}$ When Rebecca and Magawisca are imprisoned, they are offered cruel bargains that serve to point out the constraints women face when their people are being conquered. Each of the two women is offered a reprieve if she will convert to Christianity (Ivanhoe 330, Hope Leslie 279), yet each refuses, even though she may thereby condemn herself to death. ${ }^{15}$ In Ivanhoe, Bois-Guilbert says he will rescue 
Rebecca if she becomes his mistress, but she turns him down (342-43). In Hope Leslie, Sir Philip Gardiner, whose libertinism, hypocrisy, and irresolution advertise his kinship to Bois-Guilbert, demands Magawisca repay him if he helps her escape. ${ }^{16}$ Gardiner's proposal is admittedly more modest than the Templar's: he asks that Magawisca take his white mistress Rosa off his hands by transporting her into Indian territory (256-57) (he pursues Hope Leslie instead of Magawisca, and it is Hope whom he plans to abduct). ${ }^{17}$

Scott's innovation on the Pocahontas narrative is to split the heroine's rescue into two: first, Rebecca is offered a chance to escape by converting or by submitting sexually, options she refuses; second, Ivanhoe jumps at the opportunity (luckily!) to fight for her without asking for anything in return. As in the Pocahontas legend, the woman is rescued; unlike in the Pocahontas legend, her rescuer does not pursue her sexually. The woman's persecutor, however, does pursue her, and his pursuit is essential to her persecution. When a man offers to "save" Rebecca, the price is seduction, conversion, or both, so that in Scott (and later in Sedgwick), sexual joining and religious conversion are part of the problem, not part of the solution. Witnessing these offers in Ivanhoe and Hope Leslie encourages the reader to glance back at the Pocahontas legend and to perceive how coercive a situation the Indian princess was placed in.

Early on in Ivanhoe, the character who promises to serve as Scott's Pocahontasequivalent is not Rebecca but his secondary heroine, Rowena, simply because Rowena is the descendent of Saxon royalty, and the defeated Saxons are the obvious twelfthcentury equivalent for the Native Americans. Rowena suffers more than the Pocahontas of legend. Maurice De Bracy wants to marry her, and although subsequent history shows that such alliances between Norman and Saxon will bring about a new nation from which these ethnic distinctions have disappeared, Scott refuses to make the process look pretty. ${ }^{18}$ De Bracy tries to force Rowena's acquiescence by abducting her, and one motive he avows is his conviction that "the work of the Conquest should be completed" (136). ${ }^{19}$ Scott, to authenticate his portrait of Norman brutality, describes how the real-life Saxon princess Matilda hid in a convent because it was her only escape from "the licentious pursuit of the Norman nobles," and he explains that other women among the Saxon elite also resorted to this strategy (192-93).

Although Rowena is mistreated, she could fare worse. The conquered Saxons have not sunk to the bottom of twelfth-century England's social hierarchy; that spot is occupied by the Jews. Given Scott's focus on medieval prejudices and injustices, it is not surprising that his attention shifts from the Saxon Rowena to the Jewish Rebecca. Because the two women are kidnapped and are taken to Torquilstone, Reginald Front-de-Bœuf's castle, at the same time, the reader is encouraged to compare their predicaments, and to notice the differences. Whereas De Bracy proposes marriage to Rowena, Bois-Guilbert simply wants to assault Rebecca. He proclaims to her that he will not "abstain from taking by violence what thou refusest to entreaty or necessity" (198). Even after she bravely threatens suicide and he relents, he never offers to marry her, much less let her go free, but insists instead that she must become his mistress. From the first, Rebecca never expects "that either softness or ceremony would be used towards one of her oppressed race, whatever shadow of these might be preserved towards a Saxon heiress" (195). 
Rebecca's dilemma exemplifies a woman's situation when her nation's defeat is absolute. To be Pocahontas when your people are vanquished is bad enough, but to be Pocahontas when your people are despised by the vanquished and the victors alike is even worse.

As if to show what really happens to a woman if she gives herself to her nation's conquerors, Scott provides a third Pocahontas to stand alongside Rowena and Rebecca. Ulrica, the daughter of a Saxon lord murdered years before by the Normans, was both seduced and converted: she became the mistress of Front-de-Bœuf s father, and, much in the way Pocahontas took the name "Rebecca," Ulrica took the Norman name "Urfried." Now she is a savage old woman obsessed with revenge. As Ragussis points out, Ulrica's history "represents a narrative model that threatens to overtake the stories of ... Rowena and Rebecca" because her history shows how "conversion functions as a sexual transgression that is at the same time a racial erasure" (102). It is significant that Ulrica apparently never had a chance to marry the elder Front-de Bouf, nor did she become pregnant from her relations with him. No matter what the Pocahontas legend suggests, Ulrica's experience reveals that sleeping with the enemy will not produce a new nation, and to believe that it will produce one is to grab hold of flimsy consolation. In Ivanhoe, romantic love does not necessarily redeem anything, and interracial marriage is flawed as a basis or a model for coexistence. Scott depicts marriage between dominator and dominated in such a way as to expose unions between them as a pernicious ideological fiction.

When Ivanhoe extends its critique beyond domination based on ethnicity and religion to encompass domination based on gender, the resulting emphasis on women's oppression is perhaps the novel's most significant contribution (the same emphasis marks Hope Leslie). Ivanhoe uses gender and sexuality as metaphors for national, religious, and racial difference, as Ragussis has demonstrated, yet the novel ultimately pays as much attention to gender as a distinct force. Harriet Martineau argued in 1833 that "by his exhibition of what women are, and by two or three indications of what they might be," Scott "advocated the rights of women with a force all the greater for his being unaware of the import and tendency of what he was saying" (Martineau 455, 457). Ivanhoe criticism historically has tended to focus on nationality and religion, but neglect Scott's depiction of women's situation in society. ${ }^{20}$ Yet Ivanhoe, by comparing seduction to conversion, dramatizes the relations between gender domination and other kinds of domination, while demonstrating how unpredictable are the forms those relations take.

\section{II. "Passive Fortitude": When a Woman Resembles an Indian}

Armstrong and Tennenhouse insist in The Imaginary Puritan that the focus on a woman's writing of her story is distinctive to both the American Indian captivity tradition and the British domestic novel, and that this aspect of the novel cannot be explained without referring to the captivities. ${ }^{21}$ In Caught Between Worlds: British Captivity Narratives in Fact and Fiction, Joe Snader criticizes Armstrong and Tennenhouse's specific claim that the Indian captivities supplied crucial elements of the British novel, but he does not rebut their argument about gender. While Armstrong and 
Tennenhouse commit some factual errors (as Snader points out), a less direct relation between the two genres should not be ruled out. Because more women traveled to North America than to other British outposts, women's voices figured in the American captivity narrative more than they figured in the English-language captivity tradition in general (see Snader 280-81). Therefore, if captivities did influence the role of women in fiction, then the source of that influence would have to be the American captivities (even if, as Snader argues [24-25], the source cannot be Rowlandson's narrative specifically). In general, stories of contact between Europeans and Indians inspired ways of thinking about the relations between racial and gender difference, ways of thinking that the British novel increasingly exploited.

I follow Armstrong and Tennenhouse by arguing that intercultural contact in North America, including captivity, helped in the development or the institutionalization of a particular ideal of womanhood essential to the novel. My example of transatlantic influence occurs later, however, and its path of transmission is easier to trace. Indians were hardly the only model for human fortitude, but they were repeatedly used to exemplify it, and they particularly exemplified the kind of strength women supposedly ought to cultivate-namely, passive fortitude. Ivanhoe and Hope Leslie examine how inner strength can be developed, and they explore how ideologies of race and gender often dictate whether this strength is praised (as "resolution," "fortitude," "firmness") or sneered at (as "obstinacy"). In the process the two novels suggest how the role played by resolution and fortitude in the emergent ideology of domestic womanhood disempowered women even while it empowered them.

The strength that the eighteenth-century sentimental novel attributed to heroic women resembles the "passive fortitude" of the stereotypical Indian. In his History of America Robertson wrote that whereas most nations teach their soldiers to be "active, vigorous, and enterprising," Indians reserve their highest esteem for "passive fortitude" (Robertson 6: 335). ${ }^{22}$ In 1803 C. F. Volney wrote that Indian mothers boast to their children of how their relatives, "when captives at last ... bore their torments without shrinking” (Volney 404-05). At least some white commentators saw Indians' strength in defeat as noble. According to Jonathan Carver's Travels Through Interior Parts of North America, first published in 1778, Indians "bear every species of misfortune with a degree of fortitude which has not been outdone by any of the ancient heroes of either Greece or Rome" (341-42). Scott's friend Washington Irving wrote in The Sketch Book (1819-20) that "No hero of ancient or modern days can surpass the Indian in his lofty contempt of death, and the fortitude with which he sustains its cruelest infliction" (231). Yet not all commentators were so willing to grant nobility to the Indian, and some cited as signs of Indians' irredeemability the very same traits that in non-Indians they would deem virtues. Sedgwick was particularly critical of this double standard: in her preface to Hope Leslie, she complains that when Indians choose death over captivity, white historians sneer at their "stupid or malignant obstinacy," whereas a Pequot historian might "with more justice" credit them with "high-souled courage and patriotism" (6; see also 54). ${ }^{23}$ According to Sedgwick, if American Indians in general "exulted in torture," it was because they "could not submit, and live" (6). 
Pocahontas was venerated, but Rebecca is harassed, and so the determination Pocahontas displays in saving John Smith, Rebecca must summon in order to save her honor. She shares Pocahontas's Indian strength of will, but Rebecca's strength is strength exercised, like that of the cornered Pequots, in defeat. Arguably the most significant episode in Ivanhoe is the sequence of chapters in which three characters find their fortitude put to the test. A band of Normans disguised as Saxons kidnap Rowena, Cedric, Athelstane, Rebecca, her father Isaac, and the injured Ivanhoe, and take them to Front-de-Bøuf's castle. In three successive chapters, each of the three main Norman villains (Front-de-Bœuf, De Bracy, Bois-Guilbert) attempts to extort what he wants from a captive. First, Front-de-Bœuf threatens to roast Isaac unless he surrenders one thousand silver pieces. Isaac gives in, but after he learns that Rebecca will nonetheless remain Bois-Guilbert's prisoner, he refuses to pay, vowing to demonstrate that "the Jew, amidst his tortures, [knows] how to disappoint the Christian" (186). Isaac, faced with the same method of torture Indians inflicted on their captives, displays passive fortitude worthy of an Indian warrior. Second, De Bracy attempts to persuade Rowena to marry him, and he needs to threaten Ivanhoe's and Cedric's lives in order to get her to agree. Third, Bois-Guilbert threatens to assault Rebecca, but when she threatens to throw herself off the parapet, his "resolution which had never yielded to pity or distress, gave way to his admiration of her fortitude" (199). ${ }^{24}$ However, even while Rebecca's resolution weakens Bois-Guilbert's resolve, it also excites him: “... the thought that she had her fate at her command, and could escape at will from infamy to death, gave a yet deeper colour of carnation to her complexion, and a yet more brilliant fire to her eye." Astonished to see "beauty so animated and so commanding" (200), Bois-Guilbert vows that although she must be his, "it must be with thine own consent, and on thine own terms" (201). Her threat overshoots its mark: her bravery makes her seem more beautiful, and Bois-Guilbert only wants her more.

The victims in these three confrontations are a Jewish man, a Saxon woman, and a Jewish woman. The order in which Scott recounts the three scenes (which actually occur simultaneously) makes Bois-Guilbert's assault on Rebecca the culmination of the sequence, synthesizing the preceding scenes. The two Jews are linked by their strength but the two women are not, and Rowena's weakness truly disadvantages her. Scott explains the differences between the women's reactions by pointing out how Rebecca's upbringing (195) has prepared her in ways Rowena's has failed to do (190-91). Although circumstances have made the Saxon princess appear more commanding than Rebecca, they have made Rebecca more disciplined and, ultimately, stronger. Until De Bracy's threats, Rowena exudes "courage and self-confidence" because everyone defers to her wishes, but her personality "was naturally that which physiognomists consider as proper to fair complexions, mild, timid, and gentle." So, when confronted by a man "who possessed the advantage over her, and was resolved to use it," Rowena collapses: she utters "a few broken interjections," "raise[s] her hands to heaven, and burst [s] into a passion of uncontroled [sic] vexation and sorrow" (191).

Rebecca's fortitude is learned, not merely innate. Her "natural strength of mind" has prepared her for danger, but her "habits of thought" help, too: as "the daughter of a despised race," she is "prepared to expect adverse circumstances" and has 
"acquired the firmness necessary for acting under them" (195). ${ }^{25}$ When imprisoned at Front-de-Bœuf's castle, Rebecca concludes that she has "no hope but in passive fortitude, and in that strong reliance on Heaven natural to great and generous characters" (196). Rebecca's "passive fortitude" reminds us of the "passive resistance" her father exercised two chapters earlier (180). Instead of appealing to heaven while collapsing, as Rowena does, Rebecca by trusting in God focuses her energy. However "natural" this reliance may be for Rebecca, her fortitude is so strong because she has been forced to develop it: the harassment of Jews has taught her that she would need to depend on God in this way (196).

According to the 1820 Lady's Monthly Museum review of Ivanhoe, the source of Rebecca's fortitude is not her trust in heaven or her Judaism but her womanhood: "Never did we meet with a heroine rendered so interesting by the display of the passive fortitude which is woman's proudest boast" (99). Although fortitude has been seen throughout history as masculine, at least one mode of inner strength was the province of women, or at least of certain exceptional women: namely, the passive fortitude necessary to withstand suffering, even to choose death over dishonor. The veneration of women who will die bravely long predated the Richardsonian sentimental novel, and this eighteenth- and nineteenth-century seduction tradition indicated that women's fortitude could sometimes exceed men's. Certainly Rebecca's bravery exceeds that of the men in Ivanhoe. The persecution that Jews in medieval Europe always expected to face was in fact a possibility even for a woman as privileged as Rowena. If suffering develops your fortitude, no one is likely to have more of it than a Jew or a woman (a Jewish woman perhaps has the best chance of building up her fortitude). In fact, being a Jew is good practice for being a woman, since any woman is in a similar predicament, even if she doesn't know it yet.

Moreover, in a conflict between ethnic or national groups, women pay a disproportionate price. Martineau argues that Rebecca's troubles are typical of those that women face: she is "first despised, then wondered at, and involuntarily admired; tempted, made use of, then persecuted, and finally banished-not by a formal decree, but by being refused honourable occupation, and a safe abiding place" (457). In Martineau's view, Rebecca's ethnicity should not be permitted to overshadow her gender: "As a woman, no less than as a Jewess, she is the representative of the wrongs of a degraded and despised class" (456). When Bois-Guilbert tries to frighten Rebecca by describing the execution that awaits her, she replies, "not in thy fiercest battles hast thou displayed more of thy vaunted courage, than has been shewn by woman when called upon to suffer by affection or duty" (344). If Rebecca's awareness of Jewish persecution has given her fortitude, and if fortitude is woman's proudest boast, it is equally true that women's fortitude becomes so boast-worthy because they are harassed, and they are harassed because they are women. The Lady's Monthly Museum commended women for their fortitude, but Ivanhoe suggests that such praise can hide a salient fact: women are so strong because they are abused.

Ulrica's failure is essentially a failure of inner strength. When the Saxon patriot Cedric, Ivanhoe's father, inquires why she did not kill herself years before, rather than submit to the Norman, and he asks her if she had "no poniard-no knife-no bodkin" 
(217), Scott reminds the reader that suicide was traditionally the approved defense for a besieged heroine. Rebecca is ready to escape by this route: much as Richardson's Clarissa Harlowe pointed a knife at her heart after being cornered by Richard Lovelace (Richardson 950), Rebecca prepares to throw herself from the tower to prevent BoisGuilbert's assault. But not so the young Ulrica. Presumably her education, like Rowena's, failed to school her in suffering, but she had a more decisive weakness: as she tells Isaac, her "maddening love of pleasure" (220) made her vulnerable to the elder Front-de Bœuf's advances. Her capitulation suggests that a woman must be able to shun this pleasure if she is to be resolute when resolution is necessary. Only now, when Ulrica is old, and finds "Age has no pleasure," can she learn, via Cedric's censure, the principle that "all is possible to those who dare to die" (220).

Whereas women's resolution ennobled their defeats, an "inferior" ethnic group could seldom vindicate themselves in this manner, and even though women's fortitude was usually "their proudest boast," it could be downgraded into mere obstinacy if the woman in question was a Jew or an Indian. Race still trumped gender. Rebecca and Magawisca's persecutors dismiss the women's resolution if it can be attributed to their ethnicity or religion: when Rebecca refuses to convert, the Templar Grand Master calls her an "obstinate infidel" (330); when Magawisca will neither confess nor deny the charges against her, she is accused of "the dogged obstinacy of all the Pequod race" (288). Bois-Guilbert, speaking about Rebecca's unwillingness to save her life by sharing his bed, says that she epitomizes Jews' characteristic "obstinacy" (315). According to Bois-Guilbert, her refusal to submit sexually mirrors her people's refusal to convert. Yet, no matter what these characters say, Scott and Sedgwick encourage the reader to perceive this so-called obstinacy as admirable fortitude, and to see it as, indeed, women's proudest boast. ${ }^{26}$

The kind of fortitude Pocahontas displayed when she rescued Smith is elevated by Ivanhoe, Hope Leslie, and other nineteenth-century novels into a distinctively female quality that may, unlike an Indian warrior's fortitude at the death-stake, help people. Ulrica's death, for example, facilitates the Saxons' victory at Torquilstone. Yet, while the resolute woman is made an exemplar, her resolution that helps others may help her least of all. The historical Pocahontas needed to be resolute to defend Smith, not to defend herself. Yet a Pocahontas may need to depend on her inner strength to defend her life, or, failing that, her honor; she may even be persecuted for her ability to protect men. If women shared Indians' passive fortitude, this strength did not bode well for them, given how Indians tended to get wiped out (after all, the Indian most readily praised as heroic was the doomed Indian). In fiction as in reality, passive fortitude can protect a woman's "honor," but often at the cost of her life, and celebrating it can mean acting as if active fortitude, which admittedly is often impractical, is unthinkable. Ulrica's belated resolution, though it redeems her, is not fit to be romanticized: when the Saxons defeat the Normans, a woman has to be the one to sacrifice herself. To celebrate bravery in dying entails treating such a death, or the impositions that make death the best route, as if they were inevitable. To declare, with Ulrica, that "all is possible to those who dare to die," is hardly consoling, and it may even be misleading. 
The law is more flexible in Hope Leslie than in Ivanhoe, more responsive to women's fortitude and more willing to acknowledge women's benevolent acts. Governor Winthrop and the Puritan elders display greater willingness to forgive than the Templars do. When Magawisca proclaims at her trial that she would rather die than remain captive any longer, she removes her mantle and exposes her dismemberment, thereby reminding everyone present of her heroism on Everell's behalf, and she demands from Winthrop the kindness that he promised her dying mother would be extended to her children. The spectators in the courtroom applaud Magawisca's bravery, past as well as present (293). When these fictitious Puritans unexpectedly commend the readiness to die that real Puritan historians disparaged in Indians, their reaction seems to confirm the power of an individual woman that was denied so often to a group of faceless savages. ${ }^{27}$ Sedgwick's Puritans sometimes appreciate Indian women's virtue, at least when whites benefit from it: Magawisca's mother, who protected "captive English maidens" from one of the Pequot braves $(48,56)$, is treated respectfully by the whites after she is captured. Magawisca never faces quite the doublebind Rebecca faces. Although Magawisca is put on trial, with sorcery among the accusations, her rescue of Everell always counts in her favor, as does her mother's kindness toward the English $(283,293)$. Magawisca's two rescuers, Everell and Hope, love her as a sister, and their love has been nurtured by her resolute defense of white people.

One reason oppressive law becomes vulnerable in Hope Leslie is people's responses to the fortitude of women like Magawisca and Hope. Perhaps the women's power is a sign of Sedgwick's optimism: she envisions a world where fortitude, which most of the time helps Indians and women die bravely but nothing more, can be utilized by women to save lives, maybe even their own. But women's power often lies in their submission rather than their resistance, and even passive fortitude is not passive enough. Admittedly, crying or other signs of vulnerability will not stop men who, like Indians, respect only fortitude: when Magawisca shields Mrs. Fletcher from one of the rampaging Pequot warriors, his heart is "thrilled by the courage of the heroic girl" but "untouched by the sight of the helpless mother and her little ones" (63). But whites are not Indians. Hope gets the jailer Barnaby Tuttle to cooperate by breaking into tears (308), and Sedgwick's whites generally respond more to reactions like Hope's crying than to anything else (they would also be affected by Rowena's "vexation and sorrow," which leaves De Bracy "more embarrassed than touched" [191]). Hope almost always receives what she wants because, as Tuttle observes, she "keeps the key to all hearts" (314), and tears can unlock hearts more reliably than courage does.

Perhaps Ivanhoe deserves the last word, insofar as its insistence that women are "a degraded and despised class" (Martineau's phrase) is never really rebutted by Hope Leslie. Bois-Guilbert is insensitive to "pity or distress" (Ivanhoe 199), much like the Pequot brave, so only resolution will be of use. Rebecca's willingness to die protects her for a time, but the "deeper colour of carnation to her complexion" and "more brilliant fire to her eye" (200) bring on further threats. Her resolution only makes Bois-Guilbert want her more; women's will, in general, is no weapon against their disempowerment. The resolution of men like Bois-Guilbert and Gardiner keeps crumbling, but its crumbling does not mean that a woman's fortitude will achieve very much for her. All 
those present at Rebecca's trial, even the Templar Grand Master, feel some sympathy for her (330), but she would still die at the stake if not for a bizarre deus ex machinaBois-Guilbert's contending passions do him in, just in time. Rebecca's survival rings false, and that is one reason her story as a whole rings true.

\section{Pocahontas and Hybridity}

Ivanhoe and Hope Leslie not only demythologize narratives of intermarriage and conversion, as I have said, but thereby warn us against reveling in cultural hybridity. The recent trend in scholarship toward celebration of boundary-crossing runs the risk of encouraging the observer to project onto the past the hybridity that he or she wishes to advocate. When Shelley Fisher Fishkin argues for the role of African-American English in Huckleberry Finn, she aims to pay tribute to American diversity: Twain's protagonist and narrator ought to "become an emblem of a society that is now, and has always been, as multiracial and multicultural as the sources of the novel that we have embraced as most expressive of who we really are" (Fishkin 144). ${ }^{28}$ Assertions like Fishkin's argument about language are unconvincing, however, if alternative explanations are ignored, and with Twain's protagonist the alternatives are not hard to find: as Jonathan Arac has shown, the characteristics of Huck's speech that Fishkin claims would be perceived as typical of African-American English are also found within British English (Arac 183-94). Despite her thorough research, Fishkin errs by arguing for causation even though too many causes are probable to justify her insisting that any single cause necessarily played any role at all.

Errors in method like Fishkin's, furthermore, are perhaps made more likely by her conception of the part that progressive politics ought to play in the historical analysis of culture. Was Huck Black? reproduces a liberal vision in which dominator and dominated are really partners who collaborated, by means of literal or figurative intermarriage, in producing "us." This vision becomes only more conspicuous when Fishkin employs racial difference (bloodlines, miscegenation) as a metaphor for cultural difference: the dominant critical tradition allegedly has neglected American fiction's "mixed literary bloodlines" (140); "segregation is alive and well among literary historians"; and although "laws against miscegenation have been struck from the books," nevertheless "unwritten laws prevent critics from acknowledging how fully black and white voices and traditions have mingled to create what we know as 'American' culture” (142). The mixing of specific "bloodlines" within a specific cultural text is a fact to be demonstrated, not a principle to be embraced a priori, but even if Fishkin's linguistic argument were impeccable, her enthusiasm for hybridity would still be problematic. ${ }^{29}$

My argument now folds back upon itself: Fishkin's liberal vision resembles the vision that the Pocahontas myth embodied for nineteenth-century Americans, when (to borrow Tilton's phrase), they embraced their "fantasy of absorption of the established people into the culture of the newcomers." Fishkin, by choosing racial metaphors to denote the mingling of cultural traditions, unwittingly reenacts the Pocahontas legend, which utilized the idea of racial mixing to validate the dominant culture by claiming it was Indian as well as white. Analyzing the interactions among cultures does not, 
however, justify new fantasies of absorption. As Ivanhoe and Hope Leslie indicate, hybridity is a troubling ideal, given that power relations are such that mixing is seldom an equal, cooperative affair.

I have voiced these reservations about Was Huck Black? because I believe they have implications for transatlantic cultural studies. Any given culture is hybrid rather than pure, but little follows from this principle: the hybridity of a culture does not mean that it belongs to a single, pure metaculture, nor does a culture's hybridity per se tell us what cultural strands it comprises or how they got there. Thinking in terms of an Englishspeaking "larger nation," as Armstrong and Tennenhouse advocate, is a useful corrective, but unfortunately people may begin to write about a single transatlantic culture as though the Atlantic Ocean does not exist. The single-culture model may, in fact, hurt almost as much as it helps. The circulation of narratives and myths cannot be separated from the circulation of material objects (books, manuscripts, letters) or from the specific forces that determine the objects' circulation (embargoes, copyright laws, the cost of paper). Some stories will be more transatlantic than others, some crossings more likely. Furthermore, as the fortunes of the Pocahontas story indicate, the acts of translation involved in crossing the ocean-in going, for example, from Indians to English Jews and back to Indians - are as significant as the fact that the crossing occurred. When examining culture for the interweaving of strands from diverse origins, we must remember that various forces, material and ideological, can ensure that a boundary is crossed mostly in one direction, or can prevent it from being crossed at all. Wishing away such forces will only distort our perceptions of the past and the present.

\section{Notes}

[1] The most sophisticated recent attempt to bridge British and U.S. literature, Paul Giles's Transatlantic Insurrections, includes an overview and critique of previous work (see Giles 5-14). Transatlantic Romantic studies is beginning to come into its own in part because of work on "the black Atlantic." The transatlantic dimensions of prominent books like James Chandler's England in 1819 and Julie Ellison's Cato's Tears bode well. Yet until recently studies of transatlantic literary relations in the late-eighteenth and early-nineteenth centuries tended to focus on such well-documented routes across the ocean as Coleridge's influence on the Transcendentalists or Scott's influence on James Fenimore Cooper, and even if they acknowledged expansion of the canon in one national literature, they ignored it in the other. Some critics still resist widening their perspective: see Gravil for one of the most recent books to trace connections between a handful of canonical male British writers and a handful of canonical American Renaissance figures.

[2] Particularly little has been published on how United States imaginative literature registered in Britain. Surprisingly few critics, for example, have taken a look at Percy Bysshe Shelley's works in light of his favorite novelist, Philadelphia's Charles Brockden Brown, and the best essays on Shelley and Brown are seventy years old (see Solve and Sickels; for a friend's account of Shelley's enthusiasm for Brown, see Peacock 6: 77-79).

[3] As Michael Gilmore records, "out of some four hundred [fictional narratives] issued [in the United States] between 1789 and 1800, only thirty-seven had American authors" (Gilmore 626). The first eight U.S. novels to be published in Britain were Brown's Ormond (in 1800); Royall Tyler's The Algerine Captive (1802); Brown's Arthur Mervyn (1803), Edgar Huntly 
(1803), Jane Talbot (1804), and Clara Howard (1807); the anonymous Margaretta (1807); and Brown's Wieland (1811) (see Garside). There are so many titles only because of the commitment to Brown on the part of London's Minerva Press, who published all of his six novels except Wieland. A great deal of American fiction started to appear in Britain in the 1820s.

[4] On nation and gender in Romantic-era fiction, see Corbett, and Trumpener, in particular. As I will show, Ragussis is particularly illuminating on these issues.

[5] Robert Tilton points out that Scott's Rebecca resembles Pocahontas, while he does not provide a causal link (131). Sedgwick self-consciously draws the reader's attention to the obvious similarities between Pocahontas and Hope Leslie's Magawisca (6), and critics have perceived that Hope Leslie is in some respects modeled on Ivanhoe. Alide Cagidemetrio agrees with Carolyn Karcher that "Magawisca is deliberately shaped as a descendent of Scott's Rebecca," and then steps right past the argument I am making: "Like her—and like Pocahontas—she rescues the white hero, Everell Fletcher" (34; see Karcher xxxvi). At least three other novels from the 1820s United States Americanized key portions of Ivanhoe: James McHenry's The Spectre of the Forest (1823), James Kirke Paulding's Koningsmarke (1823), and James Fenimore Cooper's The Last of the Mohicans (1826). Each takes advantage of the opportunities Scott's narrative provides for exploring cultural or racial conflicts and the role of women within them. On the relationship between Ivanhoe and The Last of the Mohicans, see Dyer.

[6] The catalogue of Scott's library lists the "3rd edit." of Robertson's History of America, which was published in 1786, but the catalogue also records that the work is in three volumes, so it must include the 1796 addition, which contained Robertson's account of Pocahontas (Catalogue 204). Such influential retellings of Pocahontas's story as the Marquis de Chastellux's Travels in North-America, in the Years 1780, 1781, and 1782 (1787) and John Davis's Travels in the United States of America During 1798, 1799, 1800, 1801, and 1802 (1803) were not in Scott's library, nor are any of the books Robertson cites as sources. When Pocahontas came to England, she was presented at the court of James VI/I, and Scott may have known of her through his researches into Jacobean Britain, although she is not mentioned in the Secret History of the Court of James the First (1811) he helped compile. Scott may also have come across Thomas Moore's poem "Fragments of a Journal to G. M., Esq.." published in Moore's Epistles, Odes, and Other Poems (1806). In this poem, Moore voices his disbelief that John Smith could ever "take a fancy / To a nymph, with such a copper front as / Pocahuntas!" (159). Moore had read Chastellux (see Epistles 157n, 311n) and Davis's travels (159n); from Davis he picked up the idea that the attachment between Smith and Pocahontas was romantic. In 1826, another British author, Felicia Hemans, published a poem that was inspired by Pocahontas's rescue of Smith, "The American Forest Girl" (Hemans later read Hope Leslie, as her editor Susan Wolfson points out [Hemans, Selected Poems 389]).

[7] In December 1808 Scott attempted to procure a copy of Holmes's book so that "a young friend" could review it for the newly established Quarterly Review (see Scott, Letters 2: 136). Eventually Holmes was reviewed by Robert Southey (Shine 10), while Scott evidently held onto American Annals.

[8] Scott's knowledge of the native peoples of North America is hard to measure, although he did try to make some use of it: in The Heart of Midlothian (1817), for example, Effie Deans's son The Whistler goes to live among American Indians (Heart 506).

[9] Scott's Rebecca does not, in contrast, particularly resemble her obvious Biblical namesake, Rebecca in Genesis (Isaac's wife, Jacob's mother). Pocahontas's renaming, which Gifford and Holmes mention, is not recorded by Robertson, Chastellux, or Davis, nor is it mentioned in the Edinburgh Review notice of Davis's book, which Scott is likely to have read.

[10] Armstrong and Tennenhouse make their argument about American captivities and British novels sound provisional and tentative - "We will try to imagine ... we will try out a narrative .... We want to think ... we are suggesting that ... the perspective we are taking" (196-97) but they still commit themselves to as specific a claim as the driest historical scholarship ever put forward: "no such product of modern English culture [as the particular kind of epistolary 
heroine found in Pamela] can be explained by events occurring strictly within English culture" (199). Joe Snader, for one, has challenged Armstrong and Tennenhouse's claims for causation: in his judgment, their work exemplifies the "scholarly penchant for exaggerating the impact within the British press of captivity accounts originally published in the thirteen colonies," and he points out that Rowlandson's captivity narrative, on which Armstrong and Tennenhouse concentrate, was never reprinted in Britain in the eighteenth or nineteenth centuries (Snader 24-25; cf. Armstrong and Tennenhouse 203; Armstrong, "Captivity" 374-75). In fact, Snader observes, American Indian captivity narratives like Rowlandson's are only "one important strand within a larger Anglophone tradition of captivity narratives that began with the earliest British ventures into alien seas, during the late sixteenth century" (1).

[11] The tragedy of the aboriginal people of the New World hangs over one variant of the Pocahontas legend that Scott certainly knew, the story of Inkle and Yarico. The native West Indian woman Yarico fell in love with the Englishman Inkle, whom she hid from her cannibalistic countrymen. He took her away with him, only to sell her into slavery. This story was recorded by Richard Steele in The Spectator in 1711, and it was kept alive in a range of poetic and dramatic adaptations well into the nineteenth century (see Felsenstein). Not surprisingly, a lot of the best recent research on the "transatlantic" Romantic period has concerned slavery, the slave trade, and the campaigns against both (see Thomas; Lee).

[12] Bear in mind: I have no evidence that Scott read Chastellux in particular.

[13] The notion that this passion impelled her to rescue Smith was the early nineteenth century's most significant contribution to the Pocahontas myth; the pivotal text is Davis's Travels (see Tilton 35). According to Robertson, in contrast, Pocahontas's motivation for saving Smith was merely "that fond attachment of the American women to their European invaders" (Robertson 8: 35), and in Chastellux's Travels, Smith is her "second father" (Chastellux 2: 142). Davis's modification of the story made it even easier for later retellings to compare and relate conversion and seduction.

[14] Sedgwick made the resemblance of Magawisca's trial to Rebecca's hard to miss. Magawisca arrives at the tribunal in "the peculiar costume of her people" (282), just as Rebecca does, and Magawisca's “oriental” Indian clothes (Hope Leslie's adjective, 266) remind us that Rebecca wore what the narrator terms "a sort of Eastern dress" (71). Both women are identified with Old Testament seductresses: Magawisca is deemed a "Jezabel" (282), Rebecca the Witch of Endor $(197,310)$ and a "Dalilah" (314). Scott in the trial scene satirizes the Middle Ages as "ignorant and superstitious" (327), while Sedgwick records that the Puritans held beliefs that in her own day would be limited to "the most ignorant and credulous" (286). Just as witnesses give perjured testimony detailing Rebecca's supposed supernatural feats, Sedgwick's Sir Philip Gardiner tells how he came upon Magawisca uttering "invocations to the Evil-one to aid her in the execution of her revenge on the English" (285-86). Both women win sympathy from the spectators and even the judges. Higg volunteers to find Rebecca a champion (333-34), and Ivanhoe risks his life in combat on her behalf. Just as these former patients of Rebecca's rally to her cause, one point in Magawisca's favor is her efforts and those of her late mother on behalf of defenseless English people.

[15] The Grand Master of the Templars, Lucas de Beaumanoir, will spare Rebecca's life if she becomes Christian and joins a religious order (330). Earlier Bois-Guilbert tries to force Rebecca to convert (199); apparently his intention is to protect her from anti-Semitic persecution so that she may serve as his mistress. At the novel's end Rowena attempts to persuade Rebecca that "the counsel of holy men will wean you from your unhappy law" (400), but the counsel Rebecca has so far received from holy men doesn't make conversion look promising.

[16] Again, Sedgwick's echoes of Scott are not subtle. Bois-Guilbert is a Knight of the Temple, and Gardiner takes pride in being a "knight of the holy sepulchre" (201). By repeatedly referring to Sir Philip as "the knight," Sedgwick reminds us how unchivalrous he is. Bois-Guilbert pretends to be a believing Catholic although he is a religious skeptic; Gardiner pretends to be a devoted Puritan even though he is a Catholic — to a seventeenth-century Puritan, a skeptic 
would be better. Just as Bois-Guilbert's desire for Rebecca is strengthened by her resistance, Gardiner's desire for Hope is "stimulated by the obstacles which opposed it" (316); just as the Templar's face often bears signs of the "licentious," "contending" passions that eventually kill him $(338,329,347,392)$, Gardiner's face is "deeply marked by the ravages of the passions" (124). Confronted with Magawisca's "lofty glance, and unsullied spirit" (257; see also 284), her persecutor, Sir Philip, finds his resolve buckling much like that of Scott's Bois-Guilbert.

[17] Sedgwick divides Rebecca's traits between Magawisca and Hope, as Cagidemetrio points out (34). One would predict that Rebecca's tendency to attract men will be bestowed on Hope rather than on Magawisca, since Indian woman are seldom subjects of erotic fascination in nineteenth-century American fiction. Gardiner's misplaced romantic feelings for Hope resemble Maurice De Bracy's passion for Rowena, and he has the same conviction that he can compel a woman to love him: Sir Philip is certain that "there is a potent alchymy at work for us in the hearts of you women, that turns hate to love" (321).

[18] On how Romantic fiction used intercultural marriage as a figure for England's union with (above all) Ireland, see Corbett, chap. 2; Trumpener, chap. 3. Ivanhoe is remarkable for how it emphasizes not cultural but racial difference.

[19] Ultimately Rowena weds Ivanhoe, and Scott describes their marriage as "a type of the future peace and harmony betwixt two races" (398). Of course, a wedding between a Saxon princess and a Saxon noble does not unite two "races" even if the Saxon noble serves the Norman king. As Scott notes, real Saxon-Norman marriages did occur (398), and this history makes an interesting contrast to the marriage of Pocahontas and Rolfe, which, as various commentators pointed out, failed to lead to other marriages between English and Indian (see, for example, Robertson 8: 46).

[20] Hope Leslie criticism, in contrast, has neglected none of these factors, with debate focusing on how much Sedgwick's critique of the prevalent gender ideology extends to racial ideology. Nina Baym dissents from Christopher Castiglia and others who argue that (in her paraphrase) "women wrote more empathetically about the frontier and American Indians than men, even recognizing a shared oppression under white male patriarchy" (Baym, "Putting" 234 n4; see also Baym, American Women Writers 158-59; cf. Castiglia 159-79).

[21] Armstrong and Tennenhouse's aim is to explain "why gender's power as a historical category cannot be understood within the tradition of English letters, as that tradition is currently defined" (202). They are building on Armstrong's argument in Desire and Domestic Fiction (1987) that eighteenth-century novels "used a female narrator to open a discursive space for the writing subject" and "the bourgeois subject began not only as a female subject but also as a writing subject” (The Imaginary Puritan 202).

[22] In Scott's The Surgeon's Daughter (1827), one character dreams of "the suffering of the Indian on the death-stake," and editor Claire Lamont suggests that Scott was drawing on Robertson (Scott, Chronicles 212, 473n).

[23] For a similar criticism of such inconsistencies, see Irving (232).

[24] On the ways Scott applies the word "resolution" to Bois-Guilbert's need to deal with his conflicting drives, see Dyer (particularly 350-53).

[25] Ironically, because adversity builds strength, the manly Bois-Guilbert sometimes is at a disadvantage: his bearing reflects "the exercise of unresisted authority" (40), yet without resistance his resolution has become so atrophied that it fails him repeatedly when he must deal with Rebecca. No pain, no gain.

[26] Scott's depiction of a Jew's strength is inconsistent, perhaps ambivalent, when the Jew in question is a man. Scott tells us, for example, that Isaac can stand up to the Normans' threats because of Jews' "unyielding obstinacy" and "unbending resolution" (180), and juxtaposing "obstinacy" and "resolution" in this manner leaves their relation ambiguous. Shortly afterward, Scott appears to stress the more favorable interpretation of Isaac's inflexibility: Frontde-Bœuf calls it "obstinacy" (182), but Scott a moment later deems it "resolution" (183), as if to overrule his character's bigotry. 
[27] Sedgwick's Puritans may also be stirred by Magawisca's adoption of familiar Anglo-American republican rhetoric when she demands "death or liberty" (293), Patrick Henry-style.

[28] See Fishkin (140-44). As Jonathan Arac points out, Fishkin's book articulates a familiar kind of literary nationalism by treating "Huck as the representative American, and his book as the exemplary great American book"; Fishkin's innovation lies in arguing that Huck and Huckleberry Finn also represent African-American culture (Arac 184). Arac makes the case, convincingly in my opinion, that taking advantage of Huckleberry Finn's prestige in this manner distracts us from "questioning the identification of a nation with a book, or of the United States as 'American' with this particular book" (184).

[29] This objection to Fishkin's view of hybridity is central to Arac's critique (see Arac 183-94). At times Fishkin seriously underestimates the capacity of institutional racism to co-opt American melting-pot liberalism. For example, she wonders rhetorically whether "the forces of reaction," upon learning that Huck's "voice" is "part black," will "demote Huck from his place of honor in the culture and relegate him to a lesser role in the national consciousness" (Fishkin 144). In fact, the forces of reaction in today's United States would embrace an argument that Americans are all already African American.

\section{Works Cited}

Arac, Jonathan. Huckleberry Finn as Idol and Target: The Functions of Criticism in Our Time. Madison: U of Wisconsin P, 1997.

Armstrong, Nancy. "Captivity and Cultural Capital in the English Novel." Novel: A Forum on Fiction 13.3 (1998): 373-98.

Armstrong, Nancy, and Leonard Tennenhouse. The Imaginary Puritan: Literature, Intellectual Labor, and the Origins of Personal Life. Berkeley: U of California P, 1992.

Baym, Nina. American Women Writers and the Work of History, 1790-1860. New Brunswick: Rutgers UP, 1995.

- "Putting Women in Their Place: The Last of the Mohicans and Other Indian Stories." Feminism and American Literary History. New Brunswick: Rutgers UP, 1992. 19-35.

Byron, Baron, George Gordon. Don Juan. The Complete Poetical Works. Ed. Jerome J. McGann. 7 vols. Oxford: Clarendon, 1980-93. 5: 3-662.

Cagidemetrio, Alide. "A Plea for Fictional Histories and Old-Time 'Jewesses." The Invention of Ethnicity. Ed. Werner Sollors. New York: Oxford UP, 1989. 14-43.

Carver, J[onathan]. Travels Through Interior Parts of North America, in the Years 1766, 1767, and 1768. 3rd ed. London: C. Dilly, H. Payne, and J. Phillips, 1781.

Castiglia, Christopher. Bound and Determined: Captivity, Culture-Crossing, and White Womanhood from Mary Rowlandson to Patty Hearst. Chicago: U of Chicago P, 1995.

Catalogue of the Library at Abbotsford. Edinburgh: Bannatyne Club, 1838.

Chandler, James K. England in 1819: The Politics of Literary Culture and the Case of Romantic Historicism. Chicago: U Chicago P, 1998.

Chastellux, Marquis de. Travels in North-America, in the Years 1780, 1781, and 1782. Trans. An English Gentleman. 2 vols. 2nd ed. London: G. G. J. and J. Robinson, 1787.

Cooper, James Fenimore. The Last of the Mohicans: A Narrative of 1757. Text established, with explanatory notes, James A. Sappenfield and E. N. Feltskog. Intro. James Franklin Beard. Albany: SUNY P, 1983.

Corbett, Mary Jean. Allegories of Union in Irish and English Writing, 1790-1870. Cambridge: Cambridge UP, 2000.

Davis, John. Travels in the United States of America During 1798, 1799, 1800, 1801, and 1802. London: T. Ostell, 1803.

Dyer, Gary. "Irresolute Ravishers and the Sexual Economy of Chivalry in the Romantic Novel." Nineteenth-Century Literature 55 (2000): 340-68. 
Ellison, Julie. Cato's Tears and the Making of Anglo-American Emotion. Chicago: U of Chicago P, 1999.

Felsenstein, Frank, ed. English Trader, Indian Maid: Representing Gender, Race, and Slavery in the New World: An Inkle and Yarico Reader. Baltimore: Johns Hopkins UP, 1999.

Fishkin, Shelley Fisher. Was Huck Black? Mark Twain and African-American Voices. New York: Oxford UP, 1993.

Garside, Peter, James Raven, and Rainer Schöwerling, general eds. The English Novel 1770-1829: A Bibliographical Survey of Prose Fiction Published in the British Isles. 2 vols. Oxford: Oxford UP, 2000.

Giles, Paul. Transatlantic Insurrections: British Culture and the Formation of American Literature, 1730-1860. Philadelphia: U of Pennsylvania P, 2001.

Gilmore, Michael. "The Literature of the Revolutionary and Early National Periods.” The Cambridge History of American Literature. Vol. I, 1590-1820. Ed. Sacvan Bercovitch. Cambridge: Cambridge UP, 1994. 539-693.

Gilroy, Paul. The Black Atlantic: Modernity and Double Consciousness. Cambridge: Harvard UP, 1993.

Gravil, Richard. Romantic Dialogues: Anglo-American Continuities, 1776-1862. New York: St. Martin's P, 2000.

Hemans, Felicia. “The American Forest-Girl." Selected Poems, Letters, Reception Materials. Ed. Susan Wolfson. Princeton: Princeton UP, 2000. 389-91.

Holmes, Abiel. American Annals; A Chronological History of America, from its Discovery in MCCCCXCII to MDCCCVI. 2 vols. Cambridge, MA: Hilliard, 1805.

Irving, Washington. The Sketch Book of Geoffrey Crayon, Gent. Vol. 8 of The Complete Works of Washington Irving. Ed. Haskell Springer. Boston: Twayne, 1978.

Jonson, Ben. The Works of Ben Jonson. Ed. W[illiam] Gifford. 9 vols. London: G. and W. Nicol, 1816.

Lee, Debbie. Slavery and The Romantic Imagination. Philadelphia: U of Pennsylvania P, 2002.

[McHenry, James.] Solomon Secondsight. The Spectre of the Forest, or, Annals of the Housatonic, A New-England Romance. 2 vols. New York: E. Bliss and E. White, 1823.

Martineau, Harriet. "The Achievements of the Genius of Scott." Tait's Edinburgh Magazine 2 (January 1833): 445-460.

Mitchell, Jerome. Scott, Chaucer, and Medieval Romance: A Study in Sir Walter Scott's Indebtedness to the Literature of the Middle Ages. Lexington: UP Kentucky, 1987.

Moore, Thomas. Epistles, Odes, and Other Poems. London: James Carpenter, 1806.

Paulding, James Kirke. Koningsmarke, The Long Finne, A Story of the New World. 2 vols. New York: Charles Wiley, 1823.

Peacock, Thomas Love. The Works of Thomas Love Peacock. Ed. H. F. B. Brett-Smith and C. E. Jones. 10 vols. 1924-34. New York: AMS P, 1967.

Ragussis, Michael. Figures of Conversion: "The Jewish Question” and English National Identity. Durham: Duke UP, 1995.

Rev. of Ivanhoe [by Walter Scott]. Lady's Monthly Museum, ser. 3, 11 (Feb. 1820): 97-101.

Rev. of Travels in the United States of America During 1798, 1799, 1800, 1801, and 1802 by John Davis. Edinburgh Review 2.4 (July 1803): 443-53.

Richardson, Samuel. Clarissa or The History of a Young Lady. Ed. Angus Ross. Harmondsworth: Penguin, 1985.

Roach, Joseph. Cities of the Dead: Circum-Atlantic Performance. New York: Columbia UP, 1996.

Robertson, William. Works. 8 vols. Oxford: Talboys and Wheeler, 1825.

Scott, Walter. Chronicles of the Canongate. Ed. Claire Lamont. Edinburgh: Edinburgh UP, 2000.

- The Heart of Midlothian. Ed. Claire Lamont. Oxford: Oxford UP, 1982.

. Ivanhoe. Ed. Graham Tulloch. Edinburgh: Edinburgh UP, 1998.

- The Letters of Sir Walter Scott. Ed. H. J. C. Grierson, assisted by Davidson Cook and W. M. Parker. 12 vols. London: Constable, 1932-37.

Secret History of the Court of James the First. 2 vols. Edinburgh: John Ballantyne, 1811. 
Sedgwick, Catharine Maria. Hope Leslie. Ed. Mary Kelley. New Brunswick: Rutgers UP, 1987.

Shine, Hill, and Helen Chadwick Shine. The 'Quarterly Review' Under Gifford: Identification of Contributors, 1809-1824. Chapel Hill: U of North Carolina P, 1949.

Sickels, Eleanor. "Shelley and Charles Brockden Brown." PMLA 45.4 (1930): 116-28.

Snader, Joe. Caught Between Worlds: British Captivity Narratives in Fact and Fiction. Lexington: UP of Kentucky, 2000.

Solve, Melvin T. "Shelley and the Novels of Brown." The Fred Newton Scott Anniversary Papers. Chicago: U of Chicago P, 1929. 141-56.

Thomas, Helen. Romanticism and Slave Narratives: Transatlantic Testimonies. Cambridge: Cambridge UP, 2000.

Tilton, Robert S. Pocahontas: The Evolution of an American Narrative. Cambridge: Cambridge UP, 1994.

Trumpener, Katie. Bardic Nationalism: The Romantic Novel and the British Empire. Princeton: Princeton UP, 1997.

Volney, C. F. A View of the Soil and Climate of the United States of America: with Supplementary Remarks upon Florida; on the French Colonies on the Mississippi and Ohio, and in Canada; and on the Aboriginal Tribes of America. Trans. C[harles] B[rockden] Brown. Philadelphia: J. Conrad, 1804.

Wallace, David. Chaucerian Polity: Absolutist Lineages and Associational Forms in England and Italy. Stanford: Stanford UP, 1997.

Young, Philip. “The Mother of Us All: Pocahontas Reconsidered." Kenyon Review 24.3 (1962): 391-415. 